\title{
Paideusis
}

\section{A Commentary on Mark Holmes' The Reformation of Canada's Schools}

\section{David MacKinnon}

Volume 13, Number 1, 2000

URI: https://id.erudit.org/iderudit/1073022ar

DOI: https://doi.org/10.7202/1073022ar

See table of contents

Publisher(s)

Canadian Philosophy of Education Society

ISSN

0838-4517 (print)

1916-0348 (digital)

Explore this journal

Cite this document

MacKinnon, D. (2000). A Commentary on Mark Holmes' The Reformation of Canada's Schools. Paideusis, 13(1), 55-59. https://doi.org/10.7202/1073022ar viewed online.

https://apropos.erudit.org/en/users/policy-on-use/ 


\section{A Commentary on Mark Holmes' The Reformation of Canada's Schools}

\section{David MacKinnon, School of Education, Acadia University}

In everything I do and say, I meet myself. Some activities, however, force me to confront my values and beliefs in a more vivid and unsettling way than others. Reading Mark Holmes' book, The Reformation of Canada's Schools, was one such activity. I do not agree with all that he offers, nor do I feel that all of his argument are necessarily well grounded, but I do believe that this is a book worth reading by anyone interested in school change.

The brief analysis that follows focuses on the central concept of the work: choice. In so doing, other aspects of the book remain silent. There is too much between the covers - page after page of assertions, challenges, and criticism - to address in a brief commentary. But in my reading of the text, everything that Holmes offers hinges on the legitimacy of school choice and the rejection of the common public school.

Holmes argues that it is imperative in a pluralist society for parents to have the option of selecting a school or school system that best mirrors their own personal values. The road to this argument resides in his assertion that no one system can satisfy the needs of all. In so saying, he takes Canada's school systems, and especially Ontario's, to task for a plethora of inadequacies, including weak academic performance, inequitable and inefficient funding schemes, an increasing inability of public schools to offer a common curriculum that speaks to burgeoning diversity of Canada's population, the existence of teaching ideologies which fly in the face of research on effective instruction, and the complicity of teacher unions in maintaining the status quo.

What remains unclear to me is whether Holmes' argument is shackled to the legitimacy of the principle of choice in a democratic society, or whether it emanates from his belief that Canada's school systems are, to a greater or lesser extent depending on the province, substandard. This is hardly a moot point, for if his position rests on an emergent disgust with the existing systems, it leaves open the legitimacy of the common school principle, or at least a common curriculum and standards in different schools, despite his claims that it is impossible to satisfy the value positions of a diverse population. That is, if substandard schools systems are the problem, we need only correct them. If, however, the argument is constructed on the principle of differentiated school systems as a fundamental tenet of a democratic

Paideusis 13:1, 2000 
and pluralist society, the excellence or lack thereof, of the common system is irrelevant. Despite his arguments for the legitimacy of choice, his stinging condemnation of Canada's educational systems leaves an element of doubt in my mind.

Following five chapters of stage setting, Holmes proposes seven schooling models that he feels would provide parents with a range of options and thus move away from the monolithic common school: (1) a strengthened area public school with clear goals established through public input; (2) the option for parents to select any school for their children within a province's boundaries, on the condition that, in most cases, parents provide transportation; (3) the provision of alternative schools or programs, including French-immersion, arts and vocational schools, and religious schools; (4) charter schools; (5) the continued existence of religious and official-language schools; (6) partially funded independent schools; and (7) direct grant schools, where parents vote to receive funding directly from the province, rather than through school boards.

Whether or not I agree with the scheme outlined by Holmes is unimportant. In a democratic tradition, each of his proposals is worthy of public debate. In the time that I have taken to read and reflect on Holmes' book, I have reached the conclusion that my objection lies not with the concept of choice per se but rather with a nagging fear that in realizing these choices within a pluralist society we may violate fundamental democratic principles and create a society more fragmented and encamped than the one we currently have. It seems almost undemocratic to say this, for surely reasonable choice around lifestyles, education, religion, and the like, is a comerstone of democracy. Yet, choices beget consequences, and if the consequences create situations that run counter to basic democratic principles, the legitimacy of the original choices is called into question. In essence, democracy can be used as an argument for and against choice. My position is clearly a consequentialist one (Strike and Soltis, 1992, pp. 11-17); that is, I am more concerned in this instance with the consequences of action, rather than the principles that inform it.

My starting point regarding the concept of school choice is equality of citizenship (Prycz, personal communication'). Equality of citizenship argues that democracy requires reason, debate, and quality of discourse, and that the provision of equal education is a cornerstone in its realization. Consequently, if we can demonstrate that different school systems by their very nature equip citizens differently, we can argue that such systems are undemocratic in their outcomes. While this is a theoretical construct, one never fully realized in practice, it nonetheless speaks to the importance of creating circumstances that provide for its possible realization.

If we juxtapose equality of citizenship with the realities of a pluralist soci- 
ety, we create an argument for, not against, a common education. One of the most important requirements of a democratic society is the need for citizens to live together in relative peace, regardless of their differences, with a willingness and ability to engage in open and honest dialogue about issues of common importance. Further, one of the pre-eminent needs of citizens in a pluralist democratic society, if it is to adhere to the principle of equality of citizenship, is an understanding of others' life circumstances. How can we reasonably engage in open and honest dialogue about social, political, economic, and other issues - a fundamental tenet of democracy - if we are ignorant of our fellow citizens' lived realities?

On the first point - the necessity of living together and engaging in open dialogue - we can see the potential for a differentiated school system to be counterproductive. Initially, it segregates us, thus exacerbating our differences and making the task of living and debating together more problematic, though not necessarily impossible. Furthermore, by definition, different systems provide different emphases for their students, thus raising the question of whether the principle of citizenship equality is violated. What is it that is discussed in these different academic institutions? What is emphasized? What is not? Open dialogue implies being equally equipped to do so. This is one of the central purposes of a common system. Perhaps, as Holmes suggests, it has failed us in this regard. But I remain unconvinced that a significantly differentiated system can accomplish this better than a well designed and effectively operated common system.

On the second point - the importance of understanding the lived circumstances of others - we can readily see that a differentiated system has the potential to remove the other from our view. Anthropologists have long demonstrated that the best way to understand others is to live among them. A likely consequence of a differentiated school system is that like-valued and like-circumstanced people will cluster together and the other becomes just that: the other. While Holmes does not argue for an intentional social segregation, it nonetheless may be a consequence of the principle of democratic choice.

Of course, our communities do reflect social clustering. We witness selfsegregation based on such things as wealth, religion, ethnicity, and education level. But the fact that we live different lives and hold different values is, in my opinion, insufficient reason to argue for a differentiated school system.

Pursuing the consequences of a differentiated educational system, we can highlight the ways in which it leads to unfortunate social and personal consequences. I suspect that anyone who has taught in a streamed school (as I have) - a type of differentiated system - can readily point to the ways in which streamed stu- 
dents learn to see themselves differently. This has significant consequences for behaviour, self-esteem, academic achievement, and social group membership. Differentiated schooling further exacerbates these phenomena. It allows for a form of isolation - isolation from those who are different from us. If my argument is valid that equality of citizenship in a pluralist democracy necessitates an understanding of those who differ from us - differentiated schooling becomes yet another barrier to its realization.

Holmes' argument for parental choice, despite its surface legitimacy, is an argument for a type of segregation, a practice that is fundamentally rooted in advantage for some and disadvantage for others. Again, this is not the way in which he frames his argument, nor do I have any sense that he sees segregation as a social good. But I do see it as a consequence of his position, and I am concerned that it would fundamentally work against equality of citizenship. I am reminded of the words of R. W. Connell (1993, p. 15):

I would like to shout this from the rooftops every time I hear another argument for 'gifted and talented' programs, for tougher 'standards' and stricter selection, for streaming or tracking, for merit awards and opportunity schools and honours programs - in short, for any of the hundred and one affronts to equal provision of education. An education that privileges one child over another is giving the privileged child a corrupted education, even as it gives him or her a social or economic advantage.

Holmes recognizes that social division is one objection to school choice, but argues that we are already divided on the basis of language, geography, and class. As stated previously, I do not consider an existing reality to be a sufficient basis for its further entrenchment. Democracy may be about choice, but it is also about living and debating together, and policy choices that overtly segregate are likely counterproductive to equality of citizenship.

Living together and engaging is spirited public debate is messy. As a lived practice, democracy has been under assault in recent decades, a situation that Lasch (1995) attributes in part to a decline in public debates brought on by a citizenry who know far less about civic affairs than in previous times (pp. 162-163). It is easy to blame the public school system for this unfortunate situation, but the schools are only one small part of a larger picture. As Lasch (p. 162) notes:

Since the public no longer participates in debates on national issues, it has no reason to inform itself about civic affairs. It is the decay of public debate, not the school system (bad as it is), that makes the public ill-informed, not withstanding the wonders of the age of information. When debate becomes a lost art, information, even though it may be readily available, makes no impression.

I am sympathetic to Holmes' concerns about a bureaucratized public school 
system. Yet, unlike him, I feel it still provides the best opportunity for the survival of democratic ways of living. I agree with him that common systems are prone to the imposition of elite value positions. However, I believe that as we become increasingly enlightened to the ways in which hegemony operates, we have the opportunity to counter its impact. I do not agree that the best way to do this is to dilute elite power by increasing system differentiation. While the differentiation argument appears good in principle, I fear the consequences will be increased conceptual and physical segregation, and diminished opportunities for equal participation in civic affairs. In short, I believe that if we give up on a common public educational system, we conceptually surrender the idea of working together for a common good not because we intend to, but because we have lost sight of, or tolerance for, others.

\section{Notes}

${ }^{1}$ Greg Pyrcz is a political philosopher in the Department of Political Science at Acadia University. I am grateful to him for helping me clarify my thinking on the concept of choice in a democratic society and the importance of equality of citizenship.

\section{References}

Connell, R. W. (1993). Schools and social justice. Philadelphia, PA: Temple University Press.

Holmes, M. (1998). The reformation of Canada's schools: Breaking the barriers to parental choice. Montreal, QC, \& Kingston, ON: McGill-Queen's University Press.

Lasch, C. (1995). The revolt of the elites and the betrayal of democracy. New York, NY: W. W. Norton \& Company.

Strike, K. A., \& Soltis, J. F. (1992). The ethics of teaching ( $2^{\text {nd }}$ ed.). New York, NY: Teachers College Press. 